\title{
FELKÉSZÍTÉS A VIRTUÁLIS ÜZLETI VILÁGRA
}

\author{
Dancsházy Kinga ${ }^{1}-$ Hampel György $^{2}$ \\ ' nemzetközi projektmenedzser, Inno-Motive Nonprofit Kft. \\ ${ }^{2}$ föiskolai docens, Szegedi Tudományegyetem Mémöki Kar
}

\section{SUMMARY}

The goal of the project developed under the Leonardo da Vinci programme, "SME's elearning to e-work efficiently" was to provide a practical and useful support for the preparation of emanagers and e-workers of small and medium-sized enterprises working in a virtual environment and to be able to be useful e-team members of virtual teams. To achieve the goals the following tasks were carried out: (1) Specification of needs; (2) Development of the on-line toolkit; (3) Development of the training material; (4) Training the e-tutors; (5) Development of the testing methodology; (6) Pilot testing on the target group; (7) Accreditation of the modules; (8) Continuous dissemination and promotion activities. The three main products of the project are the sectoral survey report, the on-line toolkit and twelve e-learning modules. All products are developed to support e-work in a virtual environment.

Kulcsszavak: Kis- és középvállalkozások, e-learning, e-munka, virtuális környezet, csapatmunka

\section{BEVEZETÉS}

A vállalkozások versenyképessége nagyobb termelékenység és hatékonyság elérésével javitható. A gazdasági környezet változásával új típusú munkaerő-piaci problémák jelentkeznek, melyek kezelése újszerủ foglalkoztatási megoldásokat igényel.

Megjelentek új rugalmas munkavállalási formák, ezek közül egyre jelentősebb a távmunka. A távmunka az információs és tudásalapú társadalom infokommunikációs eszközökkel támogatott munkavégzési formája. Jellemzően személyi számitógépen végzett olyan szellemi tevékenység, amelyben a munkavállaló otthon vagy egy közelébe kihelyezett munkahelyen, önállóan vagy virtuális csoport tagjaként old meg feladatokat a távolban lévö munkáltató megbizásából. Munkája eredményét - amely valamilyen elektronikus formában továbbítható dokumentum -, valamilyen távközlési módszerrel (interneten, intraneten vagy valamilyen elektronikus levelezörendszeren, stb.) továbbitja és többnyire a feladatokat is ugyanigy kapja. Munkáltatójával, fönökével és munkatársaival elsösorban elektronikus úton, telekommunikáció révén tartja a kapcsolatot. Személyes megjelenésére a munkáltató központjában csak esetenként van szükség (Budai, 2009).

A távmunka az egyik lehetőség a vállalkozás átszervezésére, hatékonyabbá tételére és vonzóbbá válására mind az ügyfelek mind a munkavállalók szemében. Budai munkája (Budai, 2009) alapján elönyei között lehet megemlíteni a következőket:

1. Teljesítménynövekedés, feltéve, hogy ideális esetben nem rejti magában azokat a diszfunkciókat, melyek egy valós közösségi munkavégzéssel együtt járnak. Elmaradnak például az informális beszélgetések vagy a munkába álláskor és a munka befejezésekor jelentkező ,átállási idő”. A jobb koncentráció nagyobb és jobb teljesítményt, nagyobb dolgozói produktivitást eredményez, ami növeli a cég versenyképességét.

2. Növekvő motiváltság, növekvő szabadságérzet, mobilitás, növekvő elégedettség, valamint jobb életérzés, ami a munkahely lakhelytöl, annak feltételeitől független szabad megválasztásából adódik. A munkaidő szabad meghatározása és beosztása magasabb elégedettségi szintet és szabadságérzetet generál. Akár az „élethosszig tartó nyaralás” érzete is létrejöhet.

3. Nagyobb egészség és biztonság, ami abból adódik, hogy a távmunkások egészségesebben és nagyobb biztonságban élnek, hiszen csökken a stressz és az ezzel összefüggő betegségek és kockázati tényezők; kevesebb a közlekedési baleset, hiszen kevesebben 
járnak munkába; csökken a levegöszennyezés hatása, így kevesebb lesz a légúti és allergiás megbetegedés; kisebb lesz a járványveszély.

4. A távmunkás munkavégzése független a váratlan eseményektöl, természeti csapásoktól (feltéve természetesen, hogy a bekövetkező természeti katasztrófa nem jár együtt a kommunikációs infrastruktúra összeomlásával).

5. A vállalati munkahely komfortja az otthoni munka komfortjával versenyképtelen. $\mathrm{Az}$ otthonában dolgozó ember abszolút kényelmet élvez, hiszen önmaga választja meg dolgozóhelyét, szobaját, bútorait és eszközeit.

6. Az otthon végzett távmunka esetében csökken a munkahelyre utazás költsége és időigénye, tehát a távmunka a munkavállaló számára költségmegtakarítást jelent.

7. Eredményorientált, hatékony kommunikációhoz vezet, mivel a kommunikáció a szervezés és a munkavégzés eszközévé válik: A munkavállaló és a munkáltató elsősorban elvégzendő feladatban, projektben és határidőben gondolkodik. Nem a munkavégzés mikéntje, hanem eredménye és a végrehajtandó cél lesz a kommunikáció tárgya.

8. Jobb humáneröforrás-gazdálkodáshoz vezet, ami egyrészt csökkenö betegállományban, másrészt a nagyobb számú jelölt toborzásában nyilvánul meg, hiszen a térben távol eső munkaeröpiacok is hozzáférhetővé válnak. Csökkenhet a munkaerő fluktuációja, a családi és személyes okok összeférhetősége is kezelhetöbbé válik, így a tudás és tapasztalat a szervezetnél marad.

9. A távmunka lehetővé teszi a munkanélküli, a beteg, a csökkent munkaképességü és az egyéb hátrányos helyzetü csoportok reintegrálását a munka világába.

10. Javulhat a távmunkásokat alkalmazó szervezetek társadalmi megítélése is.

Nem szabad azonban a távmunkának a felsorolt elönyei mellett a hátrányait sem elhallgatni, amelyek közül a fontosabbak (Budai, 2009):

1. A távmunka jellemzöje az egyedüllét, amely a munkavállalót megfoszthatja a társas kapcsolatok iránti igénytől, valamint a szakmai fejlödéstől is. Ennek az izolációnak részben - az e-mail, az online kommunikáció, a virtuális közösségek és a fórumok lehetnek az ellenszerei.

2. Csökkenhetnek a karrierkilátások a szervezeti elörelépés szintjén, hiszen aki nincs a látótérben, kisebb eséllyel számíthat elöléptetésre.

3. Felléphet az ún. ,hátsó udvar" szindróma, vagyis az, hogy a távmunkáért alacsonyabb bért kínálnak, holott az nem alacsony színvonalú, ,hátsó udvarban” végzett munka, csupán nem a szervezet által biztositott helységben, hanem otthon történik. Ezt még ráadásul az is erösítheti, hogy a háztartási költségek növekszenek.

4. A térben és időben különböző helyeken dolgozók kevésbé tekinthetők csoportnak, összehangolásuk több szervezőmunkát igényel, azaz a szinergiahatás csökken.

5. Eltủnhet a szervezettel szemben mutatkozó lojalitás, a szervezet politikájával történő azonosulás.

6. Elmosódhatnak a különbségek a munkahely és a magánélet között, a munkavállaló haza viszi a munkával kapcsolatos problémáit, kialakulhat a munkaalkoholizmus.

7. A távmunkához szükséges eszközök jelentős értéket képviselhetnek, így a távmunkások a vagyon elleni támadások célpontjaivá válhatnak.

8. A távmunkások felett a szervezet és a munkaadó elveszitheti az ellenörzést.

9. A bizalom elnyeréséhez munkaadói és munkavállalói oldalról egyaránt bizonyos idejü személyes érintkezésre vagy legalább több sikeres tranzakcióra van szükség, így a bizalom lassabban alakul ki.

Belátható tehát, hogy távmunka esetén a számos elöny mellett számos korlátot, akadályt is le kell küzdeni, nem csak technológiai szinten, hanem szociális és emberi erőforrás oldalról is. Ez a fajta munka új látásmódot igényel a munkában és a vezetésben is. A kulturális, földrajzi és időzónák okozta különbségek szintén kihivást jelentenek mind vezetőknek, mind a 
beosztottaknak, hiszen a beosztottak, a virtuális csapat munkáját, össze kell fogni, össze kell hangolni, értékelni kell a teljesítményüket, ösztönözni kell őket, hogy képezzék magukat és rá kell venni őket, hogy azonosuljanak a szervezettel.

\section{A PROJEKT CÉLKITÜZÉSEI}

Elmondhatjuk, hogy a vállalkozások vezetői és munkavállalók jelenleg nincsenek felkészítve arra, hogy hogyan használják az on-line eszközöket, hogyan kommunikáljanak, dolgozzanak hatékonyan együtt a virtuális környezetben. Annak érdekében, hogy a vezetők és beosztottak magabiztossá váljanak az elektronikus (virtuális) környezetben, új kompetenciák szükségesek, amelyeket mind az e-vezetőknek, mind az e-munkavállalóknak birtokolniuk kell.

Képzésre, tanulásra van tehát szükség az új képességek elsajátítása érdekében, hogy a dolgozók a jövőben potenciális és sikeres e-munkavállalókká, e-menedzserekké és virtuális csoporttagokká váljanak.

A 2009 novemberétöl 2011 novemberéig tartó $406753 €$ költségvetésü, 75\%-os EU támogatottsággal rendelkező projekt kidolgozását megelőzően az Európai Unióban nem volt eszköztár (tool-kit), illetve kompetencia alapú oktatóanyag kifejezetten arra a célra, hogy a munkavállaló meglévő kompetenciáit felmérje, majd ennek alapján elektronikus tananyag segítségével a szükséges ismereteket átadja, és ezt követően az ismeretelsajátítás fokát ellenőrizze.

A Leonardo program támogatásával megvalósitott projekt célja egy gyakorlatias és hasznos e-tananyag elkészitése volt a kis- és közepes méretü vállalkozások e-menedzserei és e-munkavállalói számára annak érdekében, hogy képesek legyenek virtuális környezetben dolgozni, illetve hasznos e-tagjai lehessenek virtuális csoportoknak. A projektben magyarok mellett több európai partner - osztrák, litván, portugál - vett részt (Inno-Motive et al., 2010).

A projekt egymás után következö célkitüzései a következök voltak:

2. Szükségletek (kompetenciák) meghatározása: Meg kellett határozni a célcsoportok (emenedzserek és e-munkavállalók) szükséges kompetenciáit a projektben részt vevő valamennyi országban. A kérdőives felmérés 200 magyar, litván, osztrák és portugál kisés középvállalkozást vizsgált. A feltárt eredmények szolgáltatták az inputot az e-tananyag elkészítéséhez. (A magyarországi felmérés e-menedzserekre vonatkozó eredménye látható az 1. ábrán.)

1. ábra: A Magyarországon végzett felmérés e-menedzserekre vonatkozó eredményei

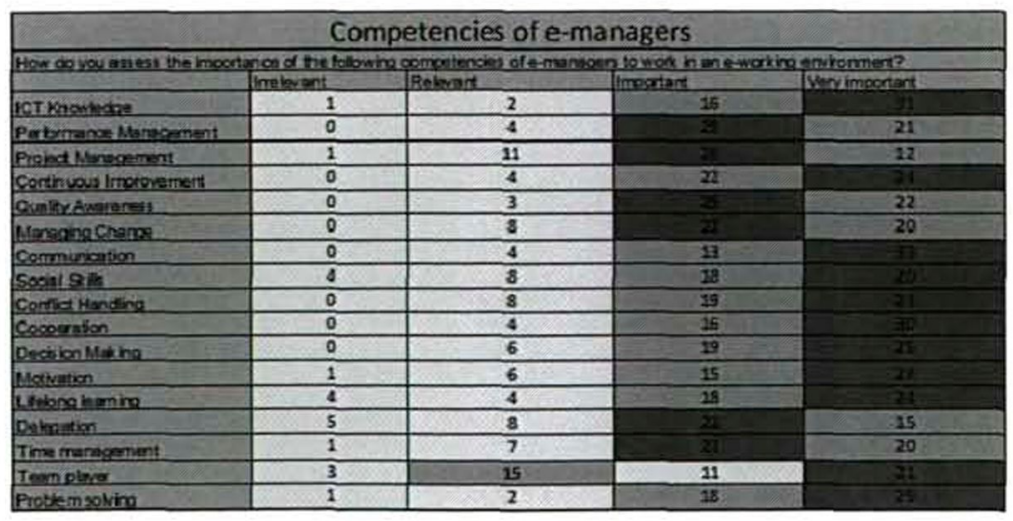

Forrás: Inovaformação Lda., 2010. 
Az eredmények szerint az e-menedzserek számára a legfontosabb kompetenciák: ekommunikáció, problémamegoldás, élethosszig tartó tanulás, csapatépítés, változáskezelés;

Az e-munkavállalók számára összességében a fontosabb kompetenciák: motiváció, ekommunikáció, minőségtudatosság, problémamegoldás, csapatépítés.

3. Az on-line eszköztár kifejlesztése: Ez az eszköztár azzal a céllal került kifejlesztésre, hogy a kérdőívekben azonosított kompetenciák birtoklását segítsen felmérni mind az emenedzserek, mind az e-munkavállalók körében. Az eszköztár segitségével, a hiányzó kompetenciák meghatározásával személyre szabott fejlesztési terv készíthető. ( $\mathrm{Az}$ eszköztár magyar nyelvü változatának egy képernyőrészlete látható a 2. ábrán.)

\section{2. ábra: A kompetencia eszköztár}

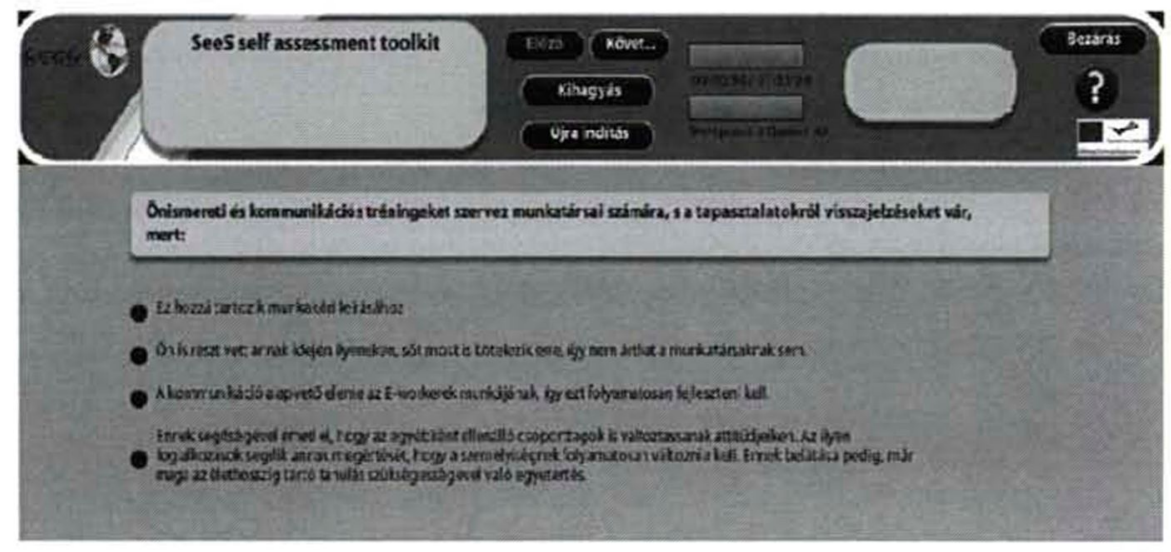

Forrás: http://seee.bitmedia.cc

4. Az oktatóanyag kifejlesztése: A kérdőivekből származó eredményekre támaszkodva 12 elearning modul kifejlesztésére került sor. A fejlesztés lépései: (1) vázlatos elképzelés, koncepció kidolgozása, (2) részletes tervezés, (3) forgatókönyv, képernyőtervek elkészítése (lásd: 3. ábra), (4) megvalósitás elektronikus formában.

\section{3. ábra: Modul képernyöterv}

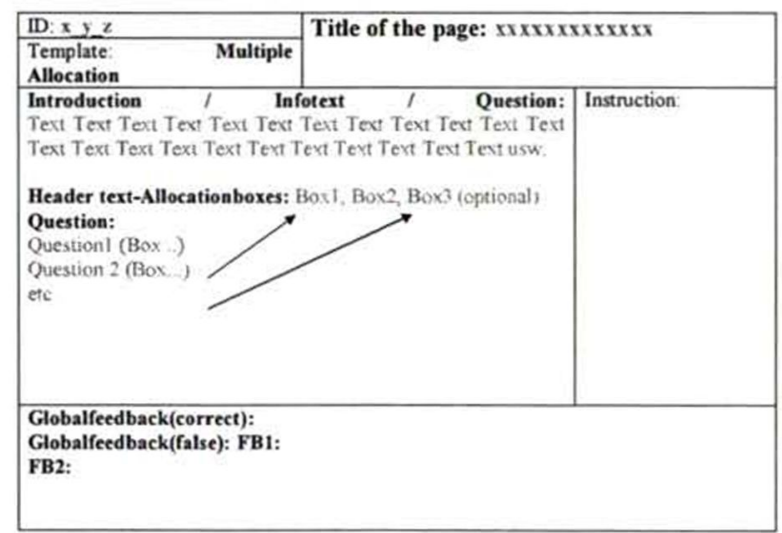

Forrás: Bit media e-learning solutions 
Minden szakasz végén történt értékelés és tartalomellenőrzés (lásd: 4. ábra). Amint megtörtént a forgatókönyvek véglegesítése, megkezdődött a modulok implementálása, először angol nyelven. Ezután következett a lokalizáció a partnerek nyelvére, így elkészült a litván, a német, a magyar és a portugál változat. Az e-menedzsereknek szánt modulok: vezetés, változásmenedzsment, teljesítményértékelés. $\mathrm{Az}$ e-munkavállalóknak szóló modulok: időgazdálkodás, döntéshozatal, problémamegoldás. A közös modulok: e-kommunikáció, csapatépítés, minőségtudatosság, motiváció, konfliktuskezelés, élethosszig tartó tanulás. A tanulók az on-line kompetencia eszköztárat és az e-tananyagot egy képzésmenedzsmentrendszer (learning management system) internet felületén érhették el (lásd: 5. ábra).

4. ábra: Modul értékelésére szolgáló űrlap (részlet)

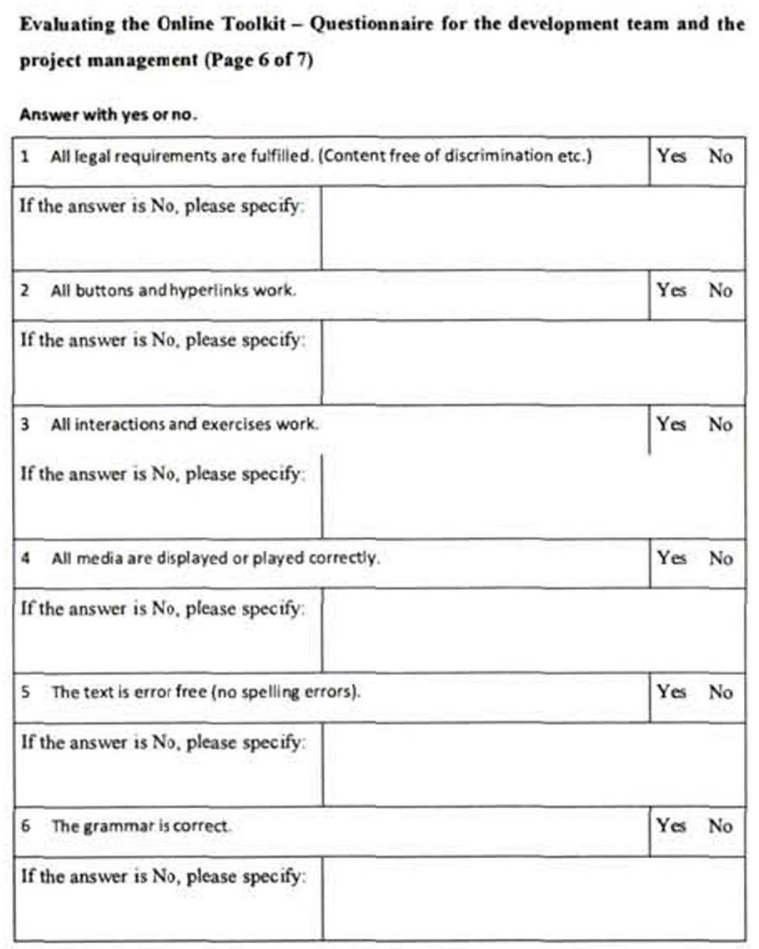

Forrás: Hampel, 2010

5. Az e-tutorok betanítása, képzése: Minden részt vevő partner országban összesen 20 e-tutor (országonként 5 fö) betanítása, kiképzése történt meg. A képzés célja az volt, hogy az oktatók megismerjék a kifejlesztett eszközöket, illetve elsajátítsák azok használatát. Az etutorok megismerkedtek az elvégzendỏ feladataikkal és az oktatás során alkalmazandó módszerekkel is, így alkalmassá váltak arra, hogy a tanulókat segítsék az e-modulok használata során.

6. Tesztelés elökészitése: A tesztelést önkéntesek végezték, akik kis- és középvállalkozások képviselői, humánerőforrás-menedzserek és oktatási intézmények képviselői voltak. Először az on-line eszköztár meghatározta azokat a területeket, amelyeknek a fejlesztése szükséges volt, azaz meghatározta mindenki számára az egyéni fejlesztési tervet. Ennek ismeretében tanulták meg a résztvevö önkéntesek a 12 modul anyagát. 
5. ábra: A képzésmenedzsment-rendszer és az e-kommunikáció modul

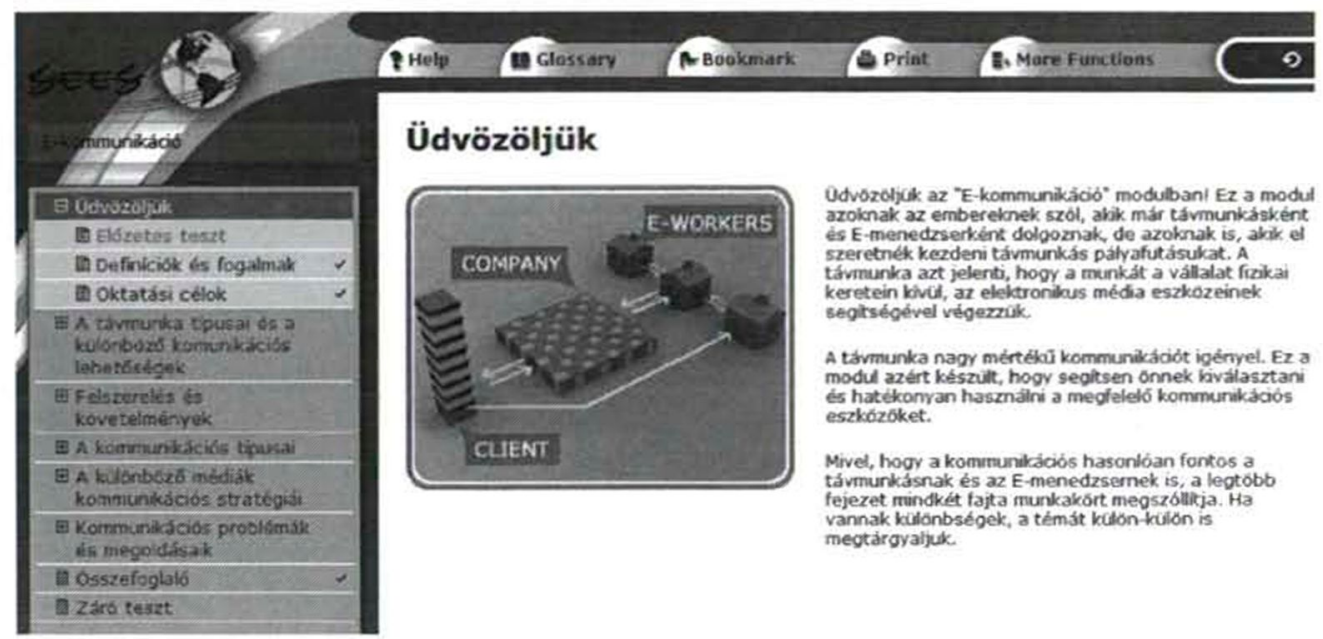

Forrás: http://seee.bitmedia.cc

7. Pilot tesztelés: A pilot tesztelés célja az volt, hogy megmutassa, mennyire képesek a gyakorlatban alkalmazni a résztvevők az oktatóanyagban elsajátított képességeket. A szimuláció valós életből vett esetek felhasználásával különböző e-munkával kapcsolatos helyzeteket tartalmazott, ahol a különböző országokban tartózkodó résztvevöknek, virtuális csapattagoknak együtt kellett müködniük, problémákat kellett megoldaniuk, döntéseket kellett hozniuk, mégpedig online kommunikációs eszközök felhasználásával.

A következő feladatokat kellett elvégezniük:

- kérdőívkészités piackutatáshoz,

- piacfelmérés a kérdöívek segitségével,

- helyzetelemzés végzése 2 országban (India, Japán),

- üzleti terv készítése a kiválasztott piacon,

- munka eredményének prezentálása bemutató formájában,

- eredmények feltöltése a projekt weboldalára.

A csapattagoknak minden online találkozó után ki kellett tölteniük egy értékelő ürlapot. $\mathrm{Az}$ e-tutor értékelte a teljesitményüket és megjegyzéseket füzött a tananyagban elsajátított tartalomhoz kapcsolódóan. A pilot csoport visszajelzései, megjegyzései be lettek épitve a végső termékbe.

8. Modulok bevezetés az oktatásba: Azt követően, hogy a lokális nyelvi változatok rendelkezésre álltak és megtörtént a pilot tesztelés is, minden partner intézmény beépitheti a tananyagot saját képzési portfoliójába. Ez - és a projekt eredményeinek számos médián keresztül történő népszerüsítése - lehetővé teszi a tananyag elterjedését és - reményeink szerint - a jövőben a 12 modulra építve lehetőség nyílik új programok és projektek felépítésére. (A projekt népszerüsítő weboldala látható a 6. ábrán.)

\section{KÖVETKEZTETÉSEK}

Ma a gazdasági válság nagy hatást gyakorol az üzleti világra, vezetőkre, munkavállalókra egyaránt. Csak azok a szervezetek maradnak meg, amelyek képesek innovatív megoldásokat találni, majd azokat alkalmazni. Azok a szervezetek maradnak fenn, amelyek akarnak változtatni, és amelyek képesek a változásokra gyorsan reagálni. Ahhoz, 
hogy a szervezet proaktív legyen, a vezetök és a munkavállalók képzése kulcsfontosságú. Fontos része a képzésnek, hogy fel kell készíteni őket egy új munkamódszerre, a virtuális csoportban végzett hatékony e-munkavégzésre, távmunkára. Az ismertetett EU projekt keretében kifejlesztett gyakorlat-orientált eszközök megfelelö segítséget nyújthatnak mindehhez.

\section{6. ábra: A projekt honlapja}

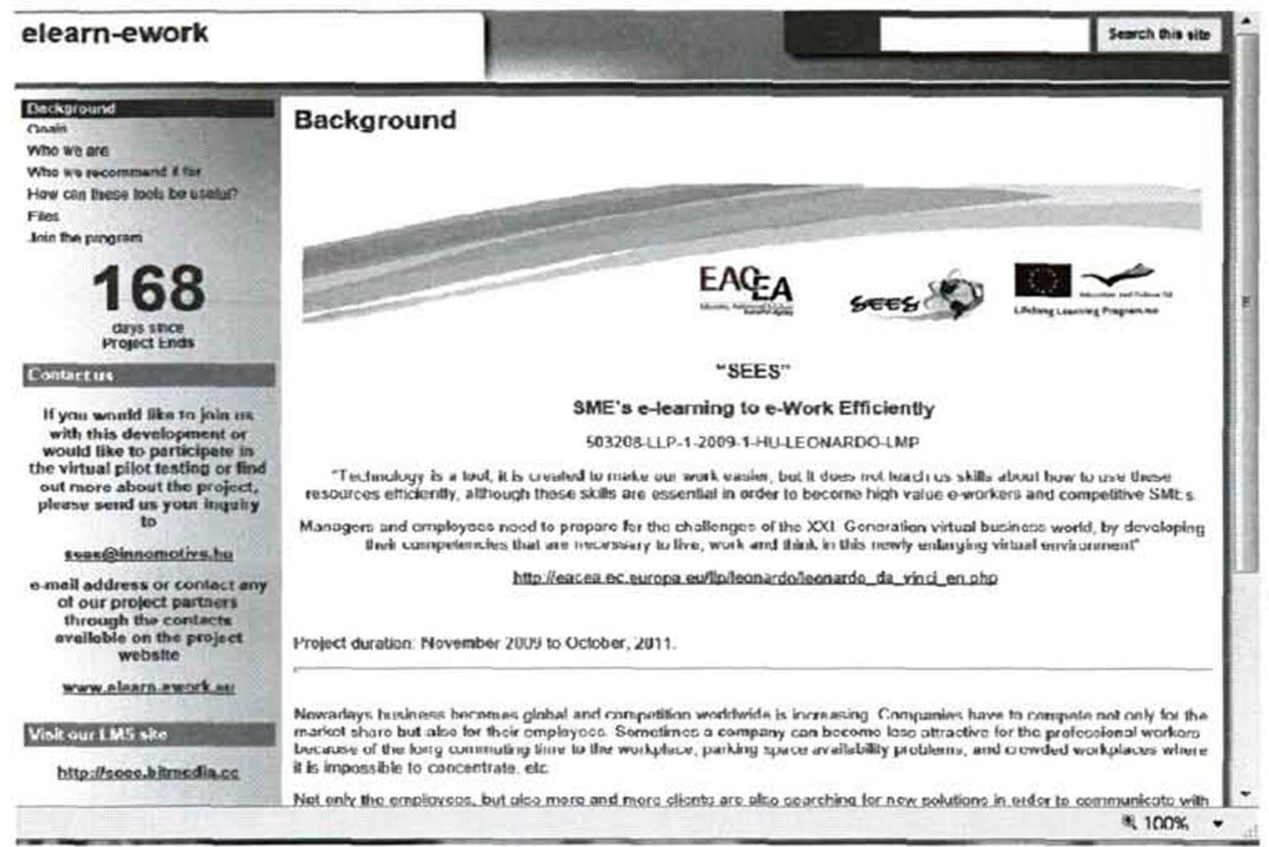

Forrás: https://sites.google.com/site/elearnework/

\section{IRODALOMJEGYZÉK}

Budai Balázs Benjámin (2009): Az e-közigazgatás elmélete. Akadémiai kiadó. Budapest. Hampel György (2010): Evaluation Handbook. Kézirat. Inno-Motive Nonprofit Kft. Szeged. Bit media e-learning solutions (2009): Content Development. Kézirat.

Inno-Motive Nonprofit Ltd. Hungary, Bit media e-Learning solution GmbH \& Co Austria, Vakaru Lietuvos versio kolegija Lithuania, Inovaformacao - Prestacao de Servicos de Formacao Pro. Lda Portugal (2010): SeeS-SME's e-learning to e-work efficiently. Progress Report. Kézirat. Inovaformação, Lda. (2010): SeeS-SME's e-learning to e-Work efficiently. Sectoral Survey Report v1.1. Kézirat.

SeeS-SME's e-learning to e-Work efficiently project website. https://sites.google.com/site/elearnework (2012.08.31.) SeeS-SME's e-learning to e-Work efficiently LMS website. http://seee.bitmedia.cc (2012.08.31.) 